\title{
THE CREATIVE CITY CONCEPT AND CITY DEVELOPMENT
}

\author{
Brygida SMOŁKA-FRANKE \\ The Silesian University of Technology, Department of Organisation and Management, Faculty of Applied Social \\ Sciences, Gliwice; brygida.smolka-franke@polsl.pl, ORCID: 0000-0003-0741-0267
}

Purpose: The concept of "creative city" is becoming more and more popular in urban development theories. The development of the city was often associated with economic and spatial development. The development of broadly understood culture and creative industries was not always taken into account or appreciated. However, analyzes and studies of cities characterized by dynamic development showed a strong dependence of their development on the factor of creative industries. The concept of a "creative city" was developed and described in detail in his publications by Charles Landry, proving how the creative development of the city stimulates the rest of its life. The aim of the article is to show the practical dimension of the theory of Ch. Landry on the importance of creative industries in city development, based on the idea of the UNESCO Creative Cities Network.

Project/methodology/approach: The research method used in the article focuses primarily on the socio-economic analysis of the development of Polish cities, such as: Cracow, Katowice, Łódź and Wrocław, which are included in the UNESCO Creative Cities group.

Findings: Cities that have acquired the status of creative cities undoubtedly have enormous cultural, historical and institutional potential. However, for a city to be creative, tradition and monuments are not enough. Without innovative thinking, noticing the need to invest in the development of "creative industries", and thus attracting representatives of the so-called the creative class responsible for smart and sustainable urban development, none of these cities would be successful.

Originality/value: The article's innovation consists in an in-depth analysis of factors favoring the development of cities, with particular emphasis on the development of creative industries. The obtained results of the analysis and the formulated conclusions may allow for the use and implementation of similar solutions in other cities in order to stimulate their future development.

Keywords: creative city, smart city, urban space, sustainable urban development.

Category of the paper: empirical research. 


\section{Introduction}

One of the most important factors in the development of a modern city is creativity.

The creative industry is a very specific sector of the economy that produces goods and services with artistic and creative value. Thanks to this, it affects, among others on: quality and standard of living, sense of identity or tourism development.

Over the years, there has been a trend in which traditional sectors of the economy are losing in importance, while cultural products are becoming increasingly appreciated.

Thanks to the development of the creative industry, new jobs are created mainly for creative people who do freelance jobs. Creative industries are most often concentrated in city centers or downtown, and increasingly also in so-called iconic city districts.

Creative industries are seen as a kind of driving force for the creative economy. According to Andrzej Klasik, they can be a tool for: revitalization of city centers and old districts that are neglected, regeneration of excluded social environments and regeneration of post-industrial areas (Klasik, 2009, p. 31).

Professor Andrzej Klasik from the University of Economics in Katowice, on the basis of conducted research regarding the potential of the creative industry of the cities of the Upper Silesian conurbation, selected the cultural potential of the cities of the Upper Silesian agglomeration. He recognized then that "one can build and promote the development of Katowice as a city of high culture, music and the music industry" (Klasik, 2014, p. 3).

A few years later, the city was declared a UNESCO creative city in the field of music and eventually obtained this title in 2017.

Starting from 2013, when the first Polish city - Cracow, was awarded the title of UNESCO Creative City (in the field of literature), four more "creative" cities arrived on the map of the country.

The article aims to show how to create an urban social space and its impact on city development, using examples of the most creative Polish cities.

The analysis carried out for the purposes of the study has an explanatory and descriptive character. Accepted research methods indicate a qualitative type of research. These include both observation technique and content analysis.

Professional literature, both in the field of sociology and economics, was also used to analyze the development of creativity in urban space by the creator of the concept of "creative class" - Richard Florida, as well as the author of the concept of "creative city" Charles Landry, also Andrzej Klasik and scientists focused on issues related to with urban issues in sociology, such as: Aleksander Wallis or Bohdan Jałowiecki. 


\section{2. "Smart city" and "creative city"}

Along with the development of information and communication technologies, the idea of a "smart city", i.e. a city, which uses modern technologies to increase the interactivity and efficiency of urban infrastructure and its elements, as well as to raise the awareness of residents, has emerged.

Most definitions of "smart city" focus on information and communication technologies as the main determinant of a smart city.

A combination of different definitions of an intelligent city was presented by Professor Nicos Komninos. He noted that an intelligent city is an area with four basic elements:

- Creative population that implements intensive activities that use knowledge or a cluster of such activities.

- Effective institutions and procedures for creating knowledge that enable it to be acquired, adapted and developed.

- Developed broadband infrastructure, digital space, e-services and online knowledge management tools.

- Proven ability to innovate, manage and solve problems that appear for the first time because of innovation and management under conditions of uncertainty, they are crucial to assess intelligence (Komninos, 2008, p. 26).

In the first place, however, the author mentions an element related to social capital which is the creative population.

The existence and meaning of so-called creative classes or creative populations described by Richard Florida.

R. Florida includes two segments in the creative class. One of them is: scientists, engineers, artists, actors, designers, architects, opinion leaders, who regularly engage in creative work consisting in creating new forms or projects, and not just solving problems. The second segment is all those who work in professions requiring advanced knowledge, e.g. ICT industry, legal environment, area of financial services (Florida, 2010, p. 13).

Another important thread in R. Florida's considerations is the role of place (geographical location) in the development of creative industries. He argues that there are creative centers whose special "atmosphere" has a positive effect on the development of creative industries, regardless of factors such as natural resources, the way local policies are pursued, or the location close to transport routes. According to Florida, in the "creative era", the basic development factor is not only knowledge, but also creativity, that is creating new, useful forms from this knowledge. The economic function of a creative class is to generate economic value through creativity, which in turn defines social identity, consumption habits and the lifestyle of that class (Florida, 2010, p. 10). 
Charls Landry - the creator of the concept of creative city, defines a creative city as a process that requires a change in the way of thinking and functioning by people and institutions to one that makes it possible to understand the development of the city and solve its problems in an integrated way. Stresses that the essence of a creative city is its sustainable development, and this concept is currently one of the main in urban development sciences.

Balance according to Ch. Landry is not just about environmental issues and ecological, but also broadly understood psychological and economic balance and cultural so that the city space inspires new thinking and allows to create sustainable forms of creativity (Landry, 2013, p. 36).

The author of this thesis encourages authorities and city dwellers to look at their own history and future in order to best identify and "branding" (create a brand) their advantages. In this approach, the process of reaching creativity is equally important, what its effects, because its purpose is to reflect on how to create meaning in a given place, how to maintain it and create it again so that the place lives on constantly.

Ch. Landry distinguished several features that determine the creativity of cities and are:

- Political spheres that encourage creative attitudes.

- Diversity and uniqueness.

- Tolerance and openness of society.

- Innovation and entrepreneurship.

- Strategic leadership, vision and implementation.

- Appropriate landscape infrastructure.

- Easy access to communication and the Internet.

- High quality of life and public services.

- Effectiveness, efficiency and professionalism (Landry, 2013, p. 36).

From the city sociologist's point of view, one of the most interesting features of cities' creativity is their diversity and uniqueness. What we especially appreciate the city for is, apart from all the above mentioned by $\mathrm{Ch}$. Landry's features that make living in the city comfortable and moves freely, it is also something that determines its originality in the background of other cities, namely the special atmosphere or in other words "genius loci", which causes that some of the cities clearly stand out from the rest and that these cities are most often recognized as creative development centers.

\section{UNESCO Creative Cities Network}

On the growing influence of the importance of creativity, development on cities and their ranking the world, evidenced by the UNESCO Creative Cities Network established in 2004. This network was created to promote cooperation between cities that consider creativity as a strategic factor for sustainable development. 
Cities that aspire to be a creative city can prove themselves in such fields of activity as literature, film, music, crafts and folk art, design, use in the development of digital technology and media, and even gastronomy.

Currently, UNESCO Creative Cities Network brings together 246 centers, including four from Poland. These include, among others:

- Crafts and folk art - Kanazawa, Gabrovo, Wuhan.

- Music - Katowice, Liverpool, Seville.

- Design - Bilbao, Berlin, Seoul.

- Film - Lódź, Rome, Sydney.

- Gastronomy - Burgos, Jeonju, Panama City.

- Literature - Cracow, Wroclaw, Barcelona, Seattle.

- Media art - Austin, Guadalajara, Linz.

UNESCO argues that the city is worthy of the title of "creative city" if the city treats culture not as an addition to its strategy, but as its pillar.

The first of Polish cities that managed to obtain this title in 2013 in the field of literature is one of the oldest cities in Poland with an undeniable cultural heritage - namely Cracow.

Cracow is also the most recognizable city among Polish cities in the world. His monuments have been added to the list of the most valuable objects in the world.

In 2000, Cracow also served as the European Capital of Culture, which undoubtedly strengthened its position on the map of "cultural" cities in Europe. In 2013, however, he was recognized primarily for his huge contribution to the development of world literature, including because it is also a city of Nobel Prize winners in a distinguished field like Czesław Miłosz or Wisława Szymborska. It also hosts the most important literary events in Poland and was recognized for his contribution to combining traditional literature with technology, which is a special development factor for the creative sector.

Katowice is the second of Polish cities that deserved the title of a UNESCO creative city in 2015 in the field of music industry. Katowice also became the first City of Music from Central and Eastern Europe.

Katowice is an example of a post-industrial city that very effectively used its cultural potential, making it one of the most important assets of its development after the fall of heavy industry.

Katowice's achievements in the development of music, including the location of one of the most recognized music colleges in the country, the organization of prestigious music festivals and finally the commissioning of one of the most modern music buildings in Europe, i.e. the seat of the Polish National Radio Symphony Orchestra (photo below), became an impulse to create the capital of Upper Silesia as a city of "music industry". 


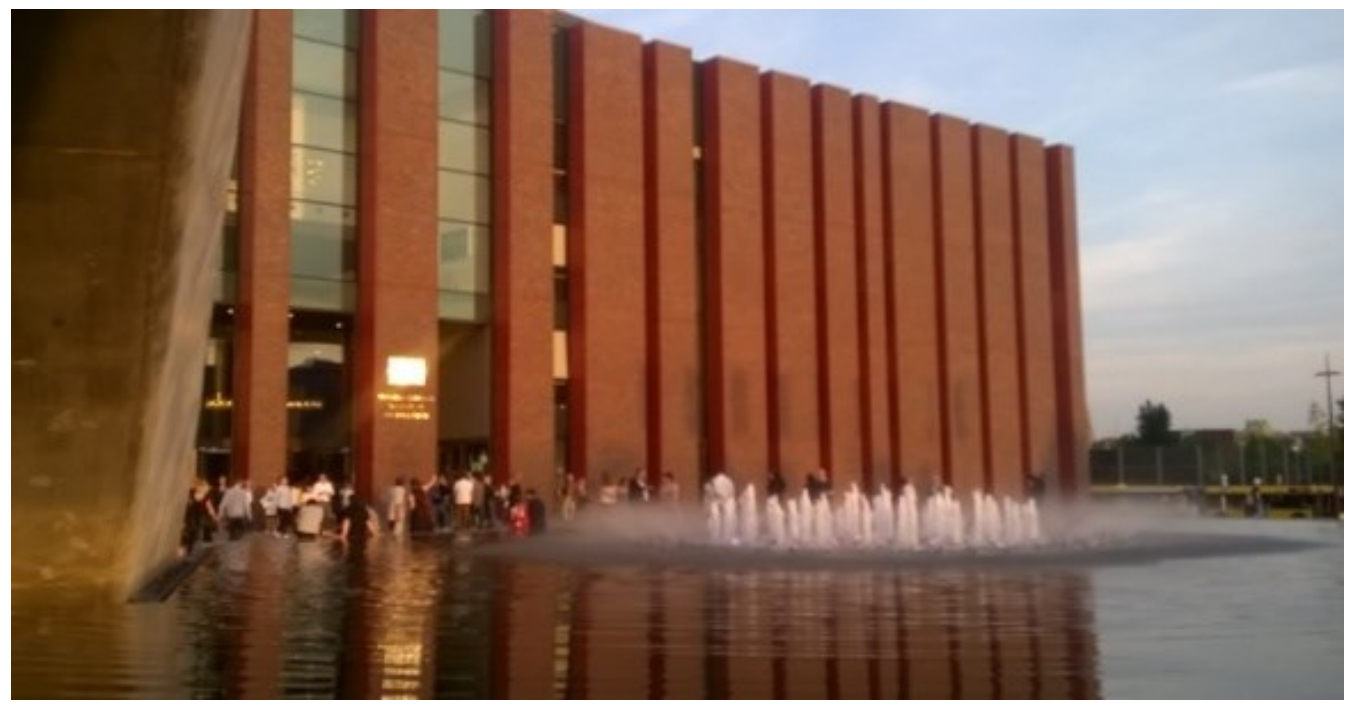

Figure 1. Modern building of the Polish National Radio Symphony Orchestra - Katowice. Source: own study.

Complementing the city's achievements in the field of music and the development of creative industries is also the creation of a prestigious and extremely attractive space known as the "Culture Zone", which was built in the vicinity of the aforementioned modern buildingof the Polish National Radio Symphony Orchestra adjacent to the famous Sports Hall "Spodek" (saucer). Nearby historic post-industrial buildings of the former "Katowice" Mine were revitalized and adapted for the modern headquarters of the Silesian Museum for the purposes of the Zone.

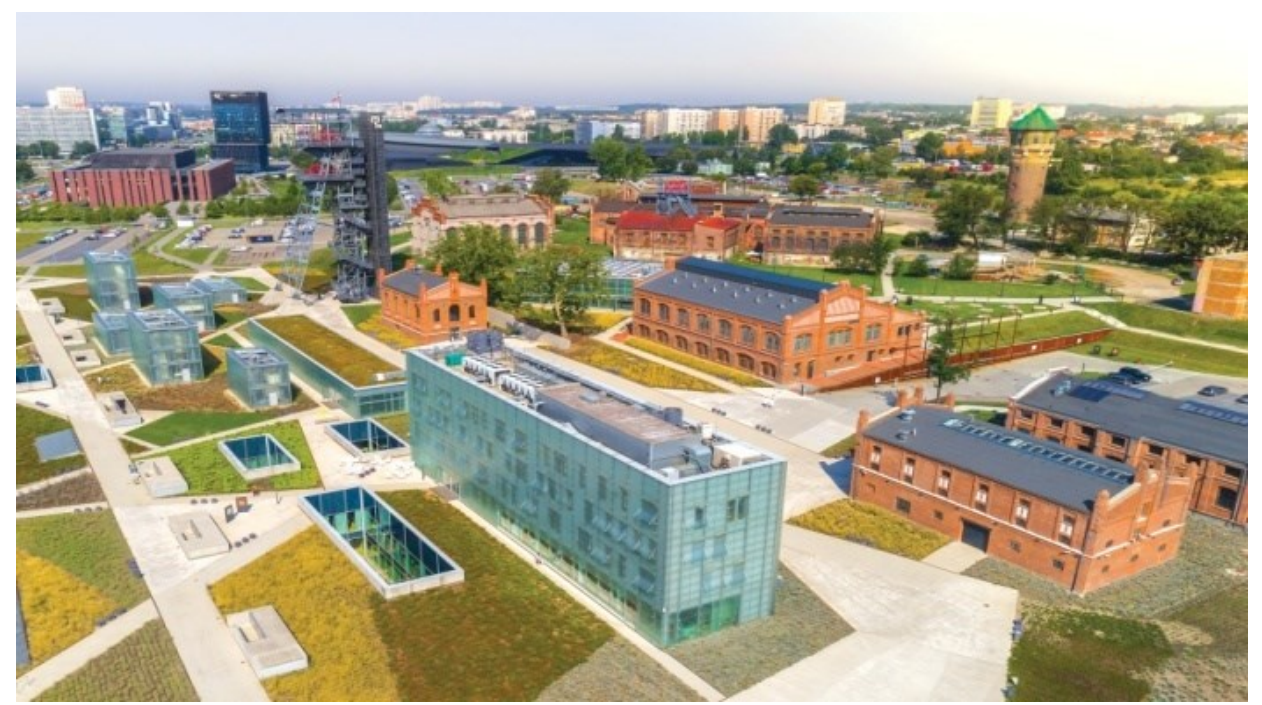

Figure 2. Culture Zone - Katowice. Source: www.katowice.eu/Strony/Strefa-kultury1201-4230.aspx.

The title of the City of Music is for Katowice, however, above all crowns the process of transformation of an industrial city into a city of creative industries. Katowice's special merit is that over the past few decades, thanks to its development strategy, the city has radically changed its face from a heavy industry center with a relatively short urban origin (compared to other creative cities in Poland) into a thriving and modern industrial center creative. 
In 2017, Łódź was the third Creative City of UNESCO in Poland in the field of film industry. Nearly half a thousand companies related to the film industry operate here, drawing on the unique heritage of the Feature Film Production Company, where the greatest masterpieces of Polish cinema were created.

Three public colleges have been educating staff for the industry throughout Poland for years. Known around the world, the Łódź Film School is honing the talents of the greatest film makers of Polish and world cinema. The Academy of Music offers studies in the field of film music composition, sound production and music in the media. Łódź is also the host of numerous film art festivals ("lodzcityoffilm", 2020).

Wrocław is the last of the Polish cities that was honored with the title of a creative city in 2019, just like Cracow in the field of literature. Wrocław as the second city in Poland (the first was Cracow in 2000) also held the function of the European Capital of Culture in 2016.

As the President of Wrocław Jacek Sutryk said: "Wrocław projects are focused supporting local creative industries related to the book, building communities around literary events and involving various groups of residents. All planned activities are implemented in the form of cooperation with other UNESCO Cities of Literature" ("wroclaw", 2020).

It can be seen that the cities considered to be the most creative are not only historically shaped dynamic urban organisms, which were naturally predestined for creative activities, but by all cities that have focused on the intensive development of creative industries, making it the basis of their development. They are also cities able to, apart from developing creative activities, create a specific "atmosphere" of the place which R. Florida mentioned.

\section{The city as a place}

The city is not only a space "furnished" with institutions, companies, communication routes or places of consumption and relaxation. Social perception of the city it is above all a special atmosphere, the "spirit of the place", which consists of aesthetic impressions, artistic sensations, often memories, history, which is all that makes the city unique and original, determines its specific climate, is its hallmark. It is this climate that attracts the city - tourists, artists, people looking for sensations, sensations - people who "revive" and shape the city.

Bohdan Jałowiecki wrote about the significance of the place: "Place is always a fragment of space distinguished, due to some special features, by the perceiving subject. Historical features can be a distinguishing place or contemporary, unique buildings, monuments, outdoor sculptures, as well as features given to some banal fragment of space by its users due to for example on an exciting event. The place is unique because it often produces a specific culture, which in turn strengthens the uniqueness of the place" (Jałowiecki, 2011, p. 12). 
In B. Jałowiecki we also read: "In the literature on the perception of space, the term magical place often appears - this adjective is to emphasize the uniqueness, beauty, mystery of the place, which not only arouses curiosity, but also evokes emotions. Photographers and painters exhibit their works, giving the exhibition the phrase "my magic place". This concept remains objectively impossible to define, because this magic of the place is a matter of subjective feelings and emotions. Can they be shared by others? Yes, although of course not by everyone, because this magic can be experienced by being equipped with a certain cultural capital" (Jałowiecki, 2011, pp. 15-16).

All of the Polish cities honored with the title of UNESCO Creative City, in addition to the listed services in a specific field of culture, also have places marked by the characteristic magic that B. Jałowiecki mentioned.

Aleksander Wallis referred to these special places with the term "cultural area", writing:"Urban space that is becoming a cultural area is carefully shaped. This means its conservation and extension or reconstruction, which preserves its basic features and structure. At the same time, it grows with feelings and ideas that find expression in art, in literary and historical works, today also in the mass media. Thanks to this, the most important cultural areas of the city are located within public reach. As a result, the most interesting cultural areas include those that are the product of long social and cultural development" (Wallis 1980, p. 71).

The special atmosphere of the place is associated with the shape of space, most often of historical significance, saturation with places that are conducive to meetings and organization of cultural and social life. The spirit of the place makes the city interesting and attracts creative people. Thus, we return to understanding the concept of a creative class and creative space discussed in the second chapter of the article.

That is why cities that understand the importance of caring for their "cultural areas" and make many efforts to develop and promote them most often.

\section{Summary and research results}

Cities that have obtained the most creative status undoubtedly have enormous cultural, historical and institutional potential.

They are usually historic cities with centuries-old tradition. Nevertheless, to make the city creative, tradition and monuments are not enough. Without innovative thinking, recognizing the need to invest in the development of "creative industries", and thus attracting representatives of the so-called creative class responsible for intelligent and sustainable city development, none of these cities would be successful. 
A perfect example of a Polish city that, despite the lack of centuries-old historical traditions, has been a huge success, becoming one of the most dynamic centers of creativity in the country are Katowice.

The capital of Upper Silesia for years was associated only with heavy industry. Despite the fact that it was a large, industrial city, for years it did not meet the criteria of a large city, such as having prestigious universities or cultural institutions. The first university the University of Silesia inaugurated its activity in Katowice only in 1968. The post-war period in Katowice is also the time of introducing architectural chaos, especially in the central area of the city, which lost its basic social and culture-forming functions.

Despite these lags, Katowice broke into one of the most dynamic creative centers in Poland and it would be difficult to expect such a spectacular success without assuming the city's vision as a thriving center for the development of creative industries and consistently implemented on the basis of this vision strategy of its development.

Creativity of cities today is primarily associated with the ability to predict and using in their development those assets that can constitute their competitive advantage. Determining the strengths of the city and their successive development may prove to be the most effective strategy on the road to the so-called intelligent development, which primarily requires attracting people to the city who will create its "creative potential".

\section{References}

1. Florida, R. (2010). Narodziny klasy kreatywnej oraz jej wptyw na przeobrażenia w charakterze pracy, wypoczynku społeczeństwa i życia codziennego. Warszawa: National Center of Culture.

2. Jałowiecki, B. (2011). Miejsce, przestrzeń, obszar. Łódź: Przegląd Socjologiczny. Lodz Scientific Society. www.yadda.icm.edu.pl/yadda/element/bwmeta1.element.desklight1f86f0a0-c77e-4cec--+a249-480c459fd646, 2017.04.28.

3. Klasik, A. (2009). Przemysty kreatywne oparte na nauce i kulturze. Katowice: University of Economics Publisher.

4. Klasik, A. Sektor kultury i przemysty kreatywne $w$ rozwoju regionu na przykladzie Aglomeracji Górnoślaskiej, 2014.08.18.

5. Komninos, N. (2008). Intelligent Cities and Globalization Innovation Networks. LondonNew York: Rutledge.

6. Landry, C. (2013). Kreatywne miasto. Warszawa: National Center of Culture.

7. Wallis, A. (1980). Pojęcie obszaru kulturowego. In: S. Nowakowski, and W. Mirowski (Eds.), Planowanie społecznego rozwoju miast $i$ społeczności terytorialnych, 
a badania socjologiczne. Wrocław-Warszawa-Kraków-Gdańsk: PWN, Institute of Philosophy and Sociology.

8. Wojnar, K. (2016). Polska klasa kreatywna. Warszawa: National Center of Culture.

9. www.creativepoland.eu/documents/bazawiedzy/n_62fb3ac_sektor_kkultury_i_przemysly _kreatywne_w_rozwoju_regionu_na_przykladzie_aglomeracji_gornoslaskiej.pdf.

10. www.lodzcityoffilm.com/lodz_miasto_filmu/lodz-kreuje-film/, 2020.04.22.

11. www.wroclaw.naszemiasto.pl/wielki-sukces-wroclaw-miastem-literatury-unesco/ar/c137407572, 2020.04.22. 